\title{
Heterotrophic components of biofilms on wood artefacts
}

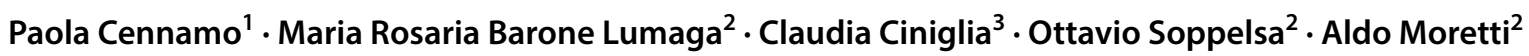

Received: 1 April 2017 / Accepted: 24 January 2018 / Published online: 26 February 2018

(C) The Japan Wood Research Society 2018

\begin{abstract}
Heterotrophic components of biofilms on wood artefacts were studied at the Conservation Laboratory for Wood Artefacts of the University Suor Orsola Benincasa of Naples, Italy. The aim of the study was to add new information on the microhabitats represented by biofilms formed by wood-dwelling organisms. Light and electron microscopy of histological features of woods used to make the artefacts showed that the woods belonged to species of lime (Tilia sp.), poplar (Populus sp.) and pear (Pyrus sp.). A Denaturing Gradient Gel Electrophoresis analysis performed on heterotrophic microorganisms colonizing the artefacts led to identify four species of bacteria, namely Bacillus cereus, B. mycoides, B. subtilis and Microbacterium oleivorans, and seven species of fungi, namely Alternaria alternata, Aspergillus fumigans, A. versicolor, Cladosporium cladosporioides, C. oxysporum, Fusarium oxysporum and Penicillium chrysogenum. Based on its morphological features, an insect found on some artefacts was identified as the xylophagous beetle Nicobium castaneum (Anobiidae). The influence of wood type and environmental conditions on the diversity of microorganisms was discussed.
\end{abstract}

Keywords Bacteria $\cdot$ Biofilm $\cdot$ Fungi $\cdot$ Insects $\cdot$ Wood

\section{Introduction}

Artefacts are continuously exposed to the effects of physical, chemical and biological factors which facilitate the growth of a wide variety of colonizing microorganisms, such as bacteria, cyanobacteria, algae, filamentous fungi and lichens, as well as of higher organisms, such as mosses, weeds and insects $[1,2]$.

The type of substrate also affects the diversity of the microbial communities, with quantity and quality of organisms varying according to whether the organisms grow on stone materials [1, 3-6] or on organic materials, such as woods and painted tissues [1]. The interactions between the organisms and the substrates, together with abiotic factors

Paola Cennamo

paola.cennamo@unisob.na.it

1 Facoltà di Lettere, University Suor Orsola Benincasa of Naples, Via Santa Caterina da Siena 37, 80135 Naples, Italy

2 Department of Biology, University of Naples Federico II, Via Foria 223, 80139 Naples, Italy

3 Department of Environmental, Biological and Pharmaceutical Science and Technology, Second University of Naples, Via Vivaldi 43, 81100 Caserta, Italy (e.g., wind, rain, humidity and pollution), cause physical, chemical and aesthetical damages to artefacts [1,3-6].

In indoor environments, as museums and exhibition halls, where the light is limited or controlled, autotrophic microorganisms are absent or rare, whereas fungi and bacteria easily grow, playing the most important role in biodeterioration processes of the artefacts; insects contribute in determining such processes $[1,7-9]$.

Particularly exposed to microbial attack in indoor environments are wood artefacts. Any deteriogenic organism finds on the wood an elective substrate for its settlement, due to porous wood structure, and diversified sources of nutrients for its growth, due to variety of organic matters supplied by the wood cellular components [10-15].

Microbial wood infections are mostly airborne and a high number of fungal and bacterial spores can accumulate in dust layers [16]. Virtually no wood exists that cannot be damaged by fungi [1]. Fungi reproduce and disperse through spores, which, after a period of quiescence, or dormancy, germinate, in some cases only after an activation phase $[17,18]$. Some chemicals, such as detergents, organic acids, alcohols and other solvents usually employed in restoration, may act as activators [14, 19]. An equally important role in the wood biodeterioration process is played by bacteria [12], especially by those 
that foster colonization of other microorganisms with the products of their metabolites $[12,20]$. The initial colonization of the wood by bacteria increases the permeability of the wood structure through the penetration of bacteria in the cavities of the cell walls, so preparing the fungal attack [21]. Other bacteria, as the cellulolytic ones, have the ability to degrade lignin and other components of the wood, resins, gums, dyes, tannic acid, waxes and fats [22]. In addition, amylolytic bacteria, as Bacillus and Clostridium, are capable of degrading the starch and lipolytic bacteria, e.g., Bacillus, Alcaligenes, Staphylococcus and Clostridium, are capable of degrading lipids thanks to the production of lipase [22, 23]; the latter microorganisms contribute in the deterioration of artefacts containing fatty substances as natural components of the wood [12, $21,24]$. Insects are also involved in determining structural alterations in the wood artefacts for their biodegradative activity [25, 26].

Several works are available which describe bacterial and autotrophic communities involved in the degradation of art objects [4-6, 15, 27], whereas comparatively fewer investigations focus on the heterotrophic microbial communities and insects responsible for the biodeterioration of wood artefacts.

In the present study, we investigated heterotrophic communities dwelling on wood artefacts, identified the type of wood used to carve the artefacts and verified the occurrence of insects on the woods. We also took into account the effects on the wood deterioration by environmental factors in the rooms hosting the artefacts.

\section{Materials and methods}

\section{Artefacts investigated}

Polychrome wood artefacts were investigated. Samples for the analyses were collected from the artefacts at the Conservation Laboratory for Wood Artefacts of the University Suor Orsola Benincasa of Naples, Italy, where the artefacts were temporary transferred to undergo restoration interventions. A description of the investigated artefacts follows.

Immacolata Concezione con Bambino (Immaculate Conception with Child) (hereinafter referred to as Artefact 1) (Fig. 1a). It is a sculpture exposed in a niche in the Sala degli Angeli (Hall of the Angels) at the University Suor Orsola Benincasa of Naples, Italy [28]. The sculpture dates back to the mid-eighteenth century $[29,30]$. The sculpture was subject to a significant biological attack by bacteria and fungi as well as by wood infesting insects [28].

Bambinello (Baby Jesus) (hereinafter referred to as Artefact 2) (Fig. 1b). It is a sculpture belonging to a private collection, dating back to nineteenth century. The sculpture presented an advanced state of biodeterioration mainly due to microbial attack.

Croce Girolamini (Girolamini Cross) (hereinafter referred to as Artefact 3) (Fig. 1c). It is a sculpture exposed at the Girolamini Museum of Naples, dating back to the fourteenth century [31]. Diffuse attacks by biodeteriogens were present on the sculpture.

Painting frames (hereinafter referred to as Artefact 4) (Fig. 1d). They are from ten paintings stored at the University Suor Orsola Benincasa of Naples. Their historical
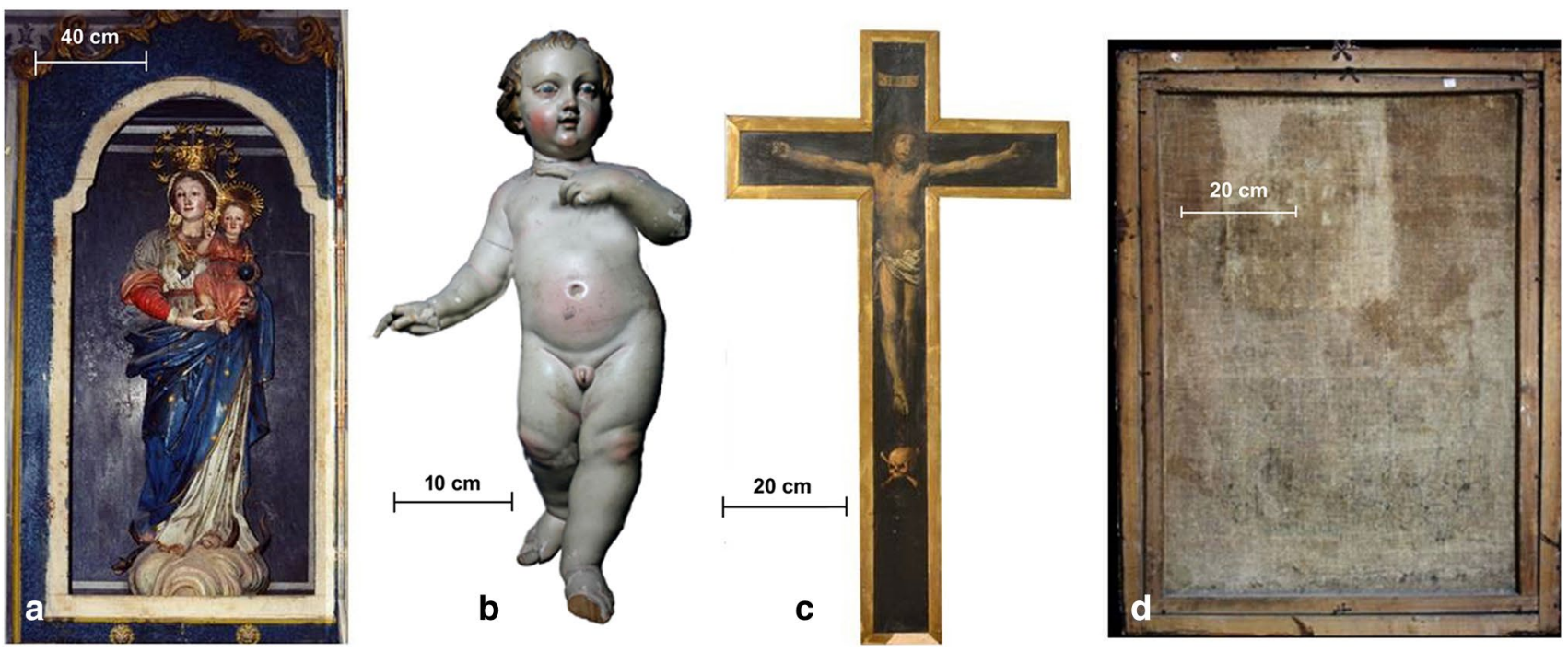

Fig. 1 Artefacts investigated. a Artefact 1, b Artefact 2, c Artefact 3, d Artefact 4 
production period is from seventeenth to nineteenth century [32]. The frames showed microbial and insects attack.

\section{Environmental factors}

Light intensity, air temperature and relative humidity values recorded over the years 2011-2016 in the rooms hosting the artefacts are summarized in Table 1 . They were provided by the Conservation Laboratory for Wood Artefacts of the University Suor Orsola Benincasa of Naples, Italy. Light intensity was measured at noon. Air temperature and relative humidity were recorded at intervals of 15 min.

\section{Identification of woods}

Micro-samples were collected from parts of woods not covered by paints or that were exposed due to fractures or removal of the paints for restoration works.

Light microscopy and scanning electron microscopy (SEM) observations of wood section features were performed for the identification of the woods. For interpretation of images, we referred to analytical keys texts [33, 34]. Terminology according to Schweingruber [34] was adopted for descriptions of characters useful for wood determination.

For light microscopy, transverse and/or longitudinal (tangential and radial) handmade sections of sampled woods were observed with a Zeiss Axiolab microscope (Zeiss, Jena, Germany) and photographed with a Nikon Digital Sight DS-L1 (Nikon, Tokyo, Japan). For SEM observations, wood samples were coated with gold to about $30 \mathrm{~nm}$. The samples were observed under a FEI Quantas 200 (FEI Company, Hillsboro, USA) environmental scanning electron microscope at an accelerating voltage of $25 \mathrm{kV}$. SEM observations were carried out at the Laboratory of Measures in Electron and Confocal Microscopy of the Centre of Advanced Metrological Services of the University of Naples Federico II, Naples, Italy.

Table 1 Averages of minimum and maximum values of temperature (T), light intensity (LI) and relative humidity $(\mathrm{RH})$ reported for the rooms hosting the artefacts over the years 2011-2016

\begin{tabular}{llll}
\hline & $\mathrm{T}\left({ }^{\circ} \mathrm{C}\right)$ & $\mathrm{LI}(\mathrm{Lux})$ & $\mathrm{RH}(\%)$ \\
\hline Artefact 1 & $17-20$ & $79-83$ & $58-68$ \\
Artefact 2 & $17-20$ & $80-120$ & $55-60$ \\
Artefact 3 & $24-28$ & $65-93$ & $65-75$ \\
Artefact 4 & $24-30$ & $73-80$ & $60-88$ \\
\hline
\end{tabular}

Standard deviations of all measured parameters values resulted within $\pm 2$

\section{Identification of insects}

For the entomological identification, the morphology and size of insects, exit holes and powdered frass were observed by an optical microscope in reflected light (Nikon SMZ 1500, Nikon, Tokyo, Japan) and photographed with a Nikon Digital-Sight DS-Fi1 (Nikon, Tokyo, Japan). The diameter of exit holes was measured by using a caliper.

\section{Sampling and cultivation of microorganisms}

Samples were collected at different times for each artefact, from 2011 to 2016, depending on the periods in which each artefact was subjected to restoration work. Samples of Artefacts 1 and 3 were collected in 2011, samples of Artefact 2 in 2016, while the samples of Artefact 4 (consisting of various wooden frames) were collected from 2011 to 2016.

Six samples were collected from each artefact. For Artefact 1 , samplings were performed on wood devoid of paint on the back of the sculpture; for the Artefact 2, on a finger of the hand and on a foot where wood was exposed for fractures; for the Artefact 3, on a not painted area on its back; and for the Artefact 4, from different areas of the frames after removal of paintings (Fig. 1).

For collecting and cultivation procedures, we followed the protocol reported by Milanesi et al. [35]. In this respect, the samples were collected by using a sterile scalpel and wiped with a sterile cotton swab. Microscopic samples were collected from all Artefacts. Isolation of microorganisms was conducted through standard microbial culture procedures. The swab was placed in test tubes with $10 \mathrm{~mL}$ of mineral medium at $\mathrm{pH}$ 6.7. The tubes were transferred to the lab where $1 \mathrm{~mL}$ of each sample was diluted in $10 \mathrm{~mL}$ sterile water and shaken for $15 \mathrm{~min}$. Resulting suspensions (about $0.5 \mathrm{~mL}$ of each sample) were inoculated in Petri plates by $5 \mathrm{~cm}$ in diameter, containing Malt agar medium [36] or Luria Bertani agar (LB) [37], and incubated for 7 days at $28^{\circ} \mathrm{C}$.

\section{DNA-based molecular analysis}

\section{DNA extraction and amplification from isolated cultures}

Genomic DNA from isolated cultures was extracted following the procedure described by Doyle [38]. For the identification of bacterial 16S rRNA sequences, DNA was amplified with the primer pair 341f/907r [39]. For the analysis of fungal sequences, fragments of about $700 \mathrm{bp}$ in size corresponding to the ITS1, the ITS2 region, the intervening 5.8S rRNA gene and small portions of $18 \mathrm{~S}$ and $28 \mathrm{~S}$ were amplified with the primer pair ITS1 and ITS4 [40].

PCR amplifications were carried out on an estimate of $10 \mathrm{ng}$ of extracted DNA, in a final volume of $50 \mu \mathrm{L}$ containing $5 \mu \mathrm{L}$ of 10X PCR buffer, $100 \mathrm{mM}$ of deoxynucleotide 
triphosphate, $2.5 \mathrm{mM}$ of magnesium chloride, $0.5 \mathrm{mM}$ of primers and $1 \mathrm{U}$ of Taq polymerase (Quiagen, Hilden, Germany). The PCR program consisted of an initial denaturation at $95{ }^{\circ} \mathrm{C}$ for $4 \mathrm{~min}$ and 30 cycles including $1 \mathrm{~min}$ of denaturation at $94{ }^{\circ} \mathrm{C}, 45 \mathrm{~s}$ of annealing at $56^{\circ} \mathrm{C}$ and $2 \mathrm{~min}$ extension at $72{ }^{\circ} \mathrm{C}$. A final extension of 7 min at $72{ }^{\circ} \mathrm{C}$ was followed by cooling at $4{ }^{\circ} \mathrm{C}$. PCR products were inspected on $1 \%(\mathrm{w} / \mathrm{v})$ agarose gels.

\section{Denaturing gradient gel electrophoresis}

Small fragments of the artefacts were collected with a sterile scalpel. Genomic DNA was extracted from these fragments using the procedure indicated above [38]. For denaturing gradient gel electrophoresis (DGGE) analysis, $200 \mathrm{bp}$ fragments of the 16S rDNA were amplified with the same primer pair as above (341f/907r) and re-amplified using the same eubacterial specific primer $341 \mathrm{f}-\mathrm{GC}$, modified with a 40-bp GC clamp added to its $5^{\prime}$ end, as a forward primer [41] and, as a reverse primer, the universal consensus primer 518r [42] (which is upstream the $907 \mathrm{r}$ primer employed in the first PCR); for the analysis of fungal sequences, the same approximately $700 \mathrm{bp}$ fragments were amplified using the same primer pair employed for isolated cultures (ITS1 and ITS4) and re-amplified with the same primer pair, except that the forward primer ITS1f-GC was modified with a 40-bp GC clamp added to its 5' end [43]. All reactions were carried out as described in Michaelsen et al. [44]. For DGGE, we used an equipment DCode TMUniversal Mutation Detection System Model 475 (BioRad, Berkeley, California). Electrophoresis was performed on $0.75 \mathrm{~mm}$ thick $6 \%$ polyacrylamide gels (37:1) with denaturing gradient ranging from 30 to $55 \%$ and $20-50 \%$ (100\% denaturant contains $7 \mathrm{M}$ urea and $40 \%$ formamide) for $16 \mathrm{~S}$ and ITS rRNA, respectively, and submerged in 1X TAE buffer ( $40 \mathrm{mM}$ Tris, $40 \mathrm{mM}$ acetic acid, $1 \mathrm{mM}$ EDTA, $\mathrm{pH}$ 7). PCR products were applied to individual lanes in the gel. Electrophoresis conditions were $16 \mathrm{~h}$ at $100 \mathrm{~V}$ and $60^{\circ} \mathrm{C}$. Gels were stained for $30 \mathrm{~min}$ in $1 \mathrm{X}$ TAE buffer with SYBR Gold nucleic acid stain and visualized using a Fluor-S MultiImager and MultiAnalyst imaging software (BioRad, Berkeley, California). DGGE fragments were sequenced after excision from gel and re-amplification. Briefly, bands were excised, re-suspended in $20 \mu \mathrm{L}$ of DNase free water and stored at $4{ }^{\circ} \mathrm{C}$ over night.

\section{Sequencing of isolated microorganisms and DGGE fragments}

The PCR products from the isolated cultures were purified with a QIAquick PCR purification kit (Qiagen $\mathrm{GmbH}$, Hilden, Germany). PCR purified products and the majority of DGGE bands were sequenced with a 3130 genetic analyzer (Applied Biosystems, Foster City, California) and their sequences were edited and aligned using the Bio Edit software (version 7) [45]. Sequences were compared with those in the GenBank/EMBL/DDBJ sequence database using BLASTN algorithm available at the National Center for Biotechnology (NCBI, https://www.ncbi.nlm.nih.gov/refseq/). For community fingerprint comparison of different samples, we quantified allele richness (number of detectable bands) for both 16S and ITS rRNA in each lane and used automatic detection of bands by UVIdoc HD5 gel documentation system (UVITEC, Cambridge, UK). Sequences were attributed to species only if percentage similarities were $>96 \%$.

\section{Results and discussion}

\section{Environmental factors}

Micro-environmental parameter values recorded in the rooms hosting the investigated artefacts (Table 1) may have contributed to favour microbial and insect growth on all the artefacts.

Relative humidity values reported for the rooms hosting the investigated artefacts (Table 1) are in all cases higher than recommended by official standard-defining documents [46]. Thus, excess humidity may have contributed to microbial and insect growth on all the artefacts, especially on Artefacts 3 and 4, which were exposed to even higher relative humidity values (Table 1). The same is true for temperature values (Table 1), higher than the recommended ones [46] for rooms hosting the Artefacts 3 and 4, which may have promoted microbial and insect growth on these two artefacts. The light intensity values measured in all rooms hosting the artefacts (Table 1) are the only values that fall within the ranges indicated as optimal [46].

\section{Woods}

The following histological characters allowed identification of the wood in each artefact:

Wood of Artefact 1: diffuse to semi-ring porous; radially orientated pore clusters; rays two- to four-seriate; height of rays very variable; ray cells small, axial oval; parenchyma apotracheal; perforation plates simple; spiral thickenings distinct; ray-vessel pits small and numerous (Fig. 2a-c). Based on these characters, the wood was attributed to a species of lime (Tilia sp.).

Wood of Artefacts 2 and 4: diffuse to semi-ring porous; pores solitary or in short radial files; rays uniseriate, average height 10 to 15 cells; ray-vessel pits large and simple; intervessel pits large; perforation plates simple (Fig. 2d, e). Based on these characters, the woods were attributed to a species of poplar (Populus sp.). 

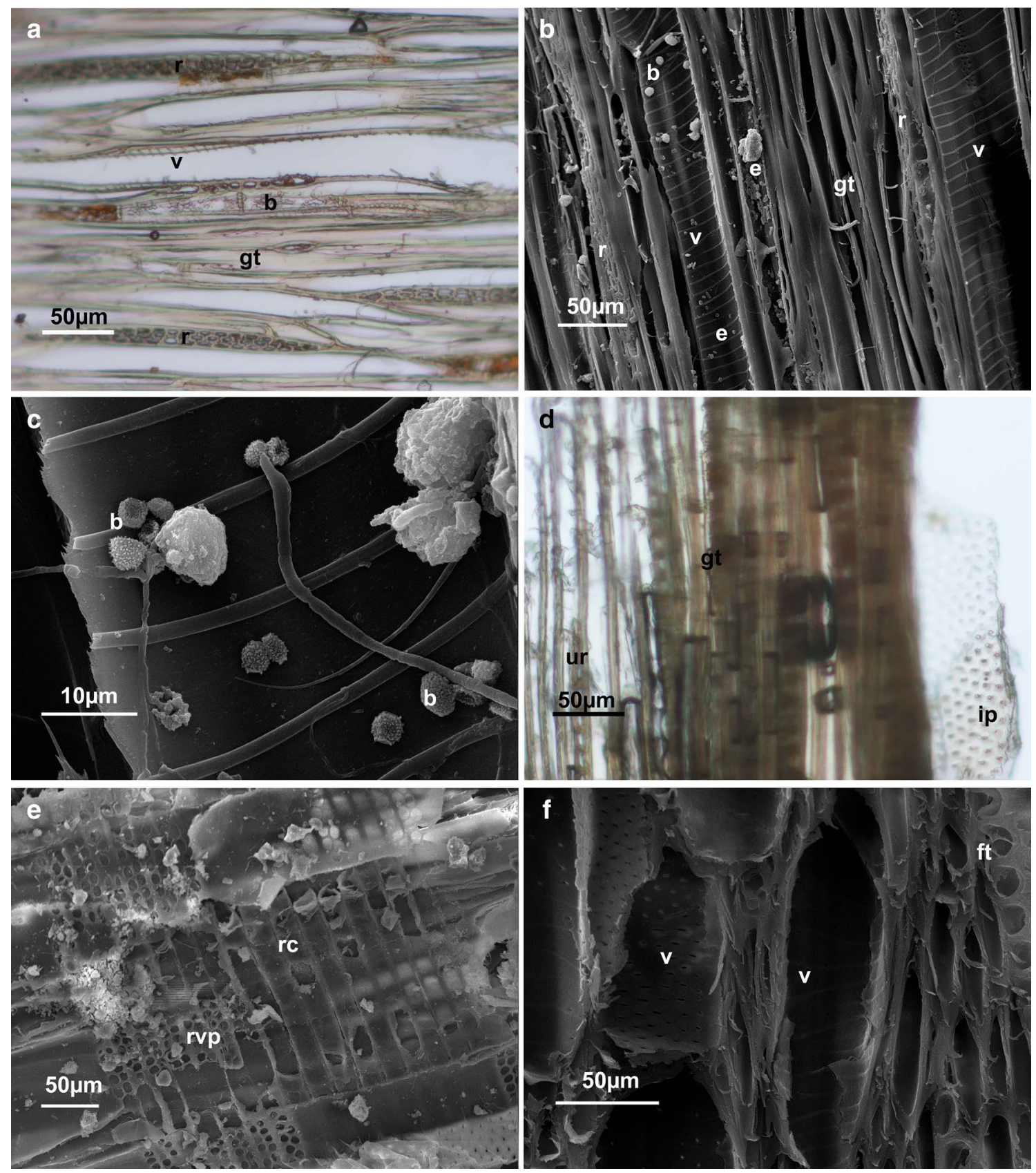

Fig. 2 a-c Tilia wood of the Artefact 1, a tangential section showing rays ( $r$ ) two- to four-seriate, a vessel (v), thin walled ground tissue (gt) and biodeteriogens (b). b Wood surface showing two vessels (v), two rays (r) and ground tissue (gt); biodeteriogens (b) and eroded area (e) are present on vessel surface. c Detail of $\mathbf{b}$ showing biodeteriogens (b) on inner surface of a vessel. d Populus wood of the

Wood of Artefact 3: rays two-, three- or seldom fourseriate; ray cells round to slightly oval-elongated; fibretracheids present; perforation plates simple; fine spiral thickening occurs in the vessels (Fig. 2f). Based on these characters, the wood was attributed to a species of pear (Pyrus sp.).
Artefact 2 Tangential section showing a vessel with intervessel pits (ip), ground tissue (gt) and uniseriate rays (ur). e Populus wood of the Artefact 4. Radial wood surface showing ray cells (rc) and large rayvessel pits (rvp). f Pyrus wood of the Artefact 3 Wood surface showing vessels (v) and fibre tracheids (ft) (a, d light microscopy; b, c, e, f scanning electron microscopy)

The lime wood identified here in Artefact 1 by light and electron microscopy confirmed a previous report by light microscopy only [28]. Lime and poplar woods were identified in a number of other wood sculptures in southern Italy $[32,47]$ and pear wood is reported to be commonly used for preparation of various artefacts of reduced sizes, included 
crosses [32]. Wood surfaces from all artefacts showed biofilms in the form of black patinas. Microbial cells were seen in some wood sections (Fig. 2a-c).

\section{Insects}

Dead insects were found on the Artefact 1 and on eight out of ten of the examined frames (Artefact 4). The other artefacts resulted free from insects. Restoration work carried out before the present study probably caused insect death on the Artefacts 1 and 4.

Data on the identification of insects occurring on the Artefact 1 were already published by two of the authors of the present work [28]. Insects found on this artefact were

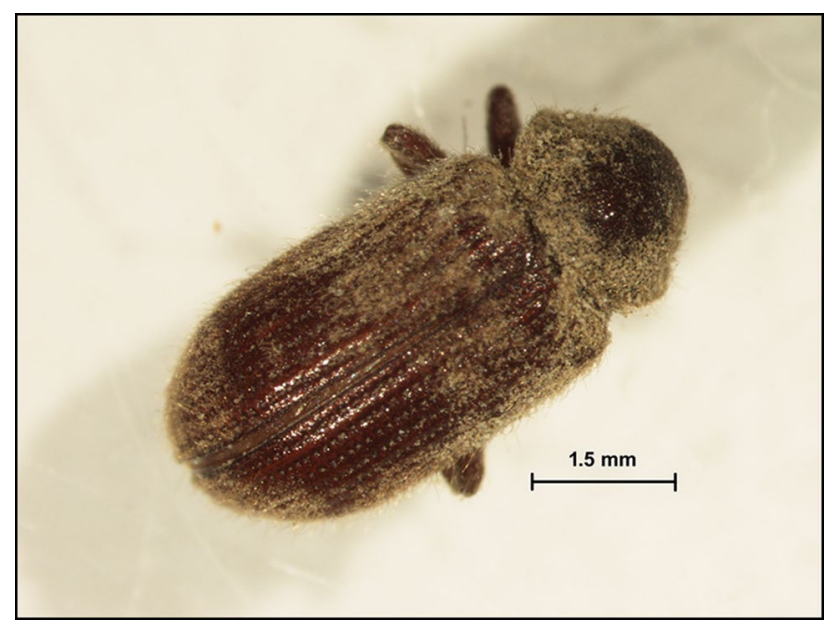

Fig. 3 The beetle infesting the Artefact 4 and identified as Nicobium castaneum referred to the beetle species Oligomerus ptilinoides (family Anobiidae) [28].

Insects found on the Artefact 4, examined in the present study, had body length of 5.8-6.2 mm, with brown setae, head recessed into the pronotum, robust mandibles; exit holes measured 1.5-2.5 $\mathrm{mm}$ in diameter and powdered frass had a gritty form. Based on such morphological features, the infesting insects were referred to the beetle species Nicobium castaneum (family Anobiidae) (Fig. 3).

Both $O$. ptilinoides and $N$. castaneum were reported as xylophagous pests on wooden sculptures in several churches in southern Italy and are known to prefer closed and humid environments [24, 26, 48]. Moreover, the presence of insect galleries, causing open spaces within the wood, was reported to promote fungal and bacterial proliferation, as insects digest cellulose thanks to the yeasts present in their midgut cecal epithelium [24, 26, 48].

\section{Microorganisms}

The microorganisms detected after culture-isolation, DNA extraction and amplification and those identified by DGGE of fragments of each artefact resulted the same, showing complete identity between the results of the two techniques.

The presences and absences of single microorganism species are reported in Table 2, separately for bacteria and fungi.

The profiles revealed a total of 11 species which were assigned to four species of bacteria and seven species of fungi (Table 2). Figure 4 shows the profiles (A: Bacteria; B: Fungi) with the highest diversity in microorganism species among all the sampling points.
Table 2 Band occurrences for each species of microorganisms identified in the four examined artefacts

\begin{tabular}{llllll}
\hline Species & $\begin{array}{l}\text { Similarity and } \\
\text { GenBank Codes }\end{array}$ & $\begin{array}{l}\text { Artefact 1 } \\
\text { (Lime) }\end{array}$ & $\begin{array}{l}\text { Artefact 2 } \\
\text { (Poplar) }\end{array}$ & $\begin{array}{l}\text { Artefact 3 } \\
\text { (Pear) }\end{array}$ & $\begin{array}{l}\text { Artefact 4 } \\
\text { (Poplar) }\end{array}$ \\
\hline Bacteria & & & & & \\
Bacillus cereus & $98 \%$ KX035061 & - & B4 & - & - \\
B. mycoides & $99 \%$ KX035066 & - & B2 & - & B2 \\
B. subtilis & $100 \%$ CP017314 & B3 & - & B3 & B3 \\
Microbacterium oleivorans & $97 \%$ KU891044 & - & B1 & - & - \\
Fungi & & & & & \\
Alternaria alternata & $99 \%$ AF404657 & F1 & F1 & - & - \\
Aspergillus fumigatus & $99 \%$ FJ878717 & - & F2 & F2 & F2 \\
A. versicolor & $98 \%$ FJ878627 & - & F4 & - & F4 \\
Cladosporium cladosporioides & $99 \%$ FJ797611 & - & F5 & - & F5 \\
C. oxysporum & $99 \%$ JQ775499 & - & F6 & - & F6 \\
Fusarium oxysporum & $100 \%$ KU129006 & F3 & - & - & F3 \\
Penicillium chrysogenum & $98 \%$ DQ249212 & - & F7 & F7 & F7 \\
\hline
\end{tabular}

Occurrences (indicated by band names as in Fig. 4) are separately reported for bacteria and fungi. The type of wood of each artefact is indicated in brackets 


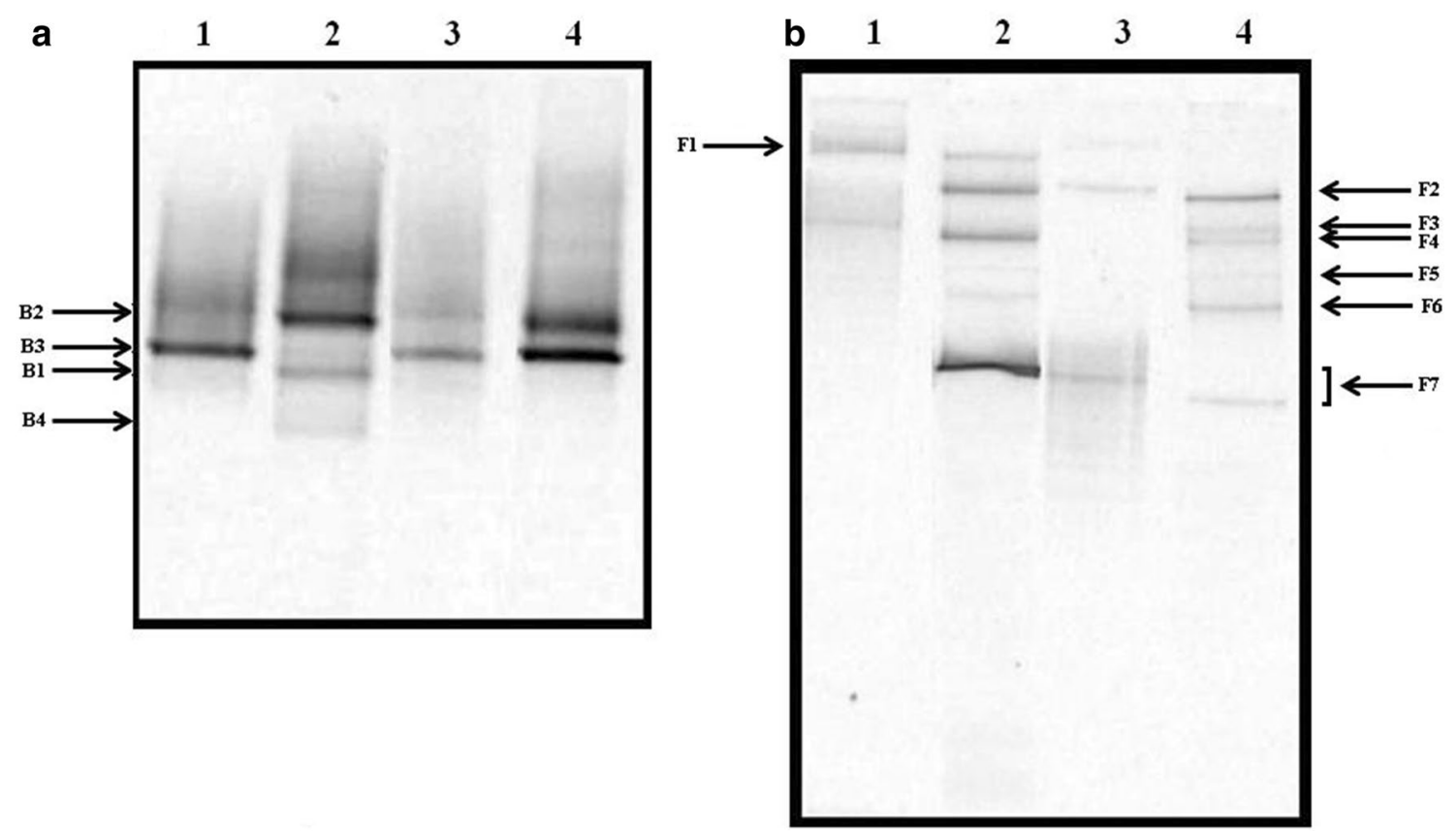

Fig. 4 One of the DGGE profiles, chosen as it shows the greatest diversity of bacteria and fungi as compared to others. Bacteria (a) and fungi (b) are in separate gels. Lanes: 1, artefact $1 ; 2$, artefact $2 ; 3$, artefact $3 ; 4$, artefact 4 . The numbered bands were excised and the

Among bacteria, Bacillus subtilis was by far the most represented species, followed by B. mycoides, B. cereus and Microbacterium oleivorans (Table 2). Among fungi, Penicillium chrysogenum, Alternaria alternata, Aspergillus fumigatus and Fusarium oxysporum resulted the most frequently found species, whereas all other species were much less represented (Aspergillus versicolor, Cladosporium cladosporioides and C. oxysporum) (Table 2).

Table 2 also shows that a higher number of species of colonizing microorganisms occurred on Artefacts 2 and 4, whereas Artefacts 1 and 3 were less colonized. As far as the frequency of species on the artefacts is concerned, among the bacteria, Bacillus subtilis was the most frequent species, occurring on three artefacts, whereas $B$. mycoides occurred on two artefacts and both $B$. cereus and Microbacterium oleivorans on one artefact only; among fungi, Penicillium chrysogenum and Aspergillus fumigatus were the most frequent species, with each of them being present on three artefacts; each of the other species was present on two artefacts only. Table 2 also shows the occurrence of species by type of wood. In this respect, Bacillus subtilis colonized three types of wood, whereas each of all other microorganisms colonized two or one type of wood. Finally, Table 2 shows the species that occur together on the substrates more frequently than others. In this respect, the most frequent association of species is represented by Aspergillus fumigatus and Penicillium chrysogenum, occurring together on three artefacts. results of species identification by sequencing the bands are shown in Table 2. B1-B4 shows bacterial DGGE bands and F1-F7 show fungal DGGE bands

We did not compute abundance of microorganisms as function of band intensity (as, for example, indicated in Formin et al. [49]) because we were primarily interested in identification, rather than quantification, of microorganismal taxa. In addition, four artefacts, even if with six sampling points each, are too small a sample to be reliably treated in a statistical fashion.

All identified microorganisms, with the exception of Microbacterium oleivorans, are known to be biodeteriogens of art-works [50].

Among bacteria, three out of four identified species belonged to genus Bacillus (Table 2). Bacillus is a genus including hundreds of strains [7], most of which were detectable in bacterial communities on indoor wood artefacts where they revealed biodegradation properties [21], including cellulolytic activity [22]. The prevalence of Bacillus on wood could be also due to the presence in its genome of genes encoding cellulose degrading enzymes, as reported for at least some species of this genus [51, 52].

It is also known that the bacteria responsible for erosion degraded the secondary wall layers using the cellulose and hemicellulose of the wood $[21,53,54]$. As a result, the residual material of the cell wall usually has a porous appearance [32]. This type of alteration was in general observed on the artefacts investigated here, in particular on Artefacts 1 and 4, which were colonized by Bacillus and presented a greater degradation state (Fig. 2e). 
Among the identified Bacillus species, as well as among all identified species, the most abundant one was $B$. subtilis in terms of occurrence on the various artefacts and types of wood (Table 2). This predominance can be explained by the presence of $B$. subtilis in various environments and by its ability to survive in harsh conditions by forming resistant endospores [55, 56]. Microbacterium oleivorans identified on the Artefact 2 only (Table 2) is a bacterial species described from oil-containing environments [50]. Its occurrence on artefacts has not been reported so far. It is noteworthy that other species of this genus are known for colonizing art-works [11] though, and that Microbacterium oleivorans can degrade crude oil [50], that is an organic compound present in dyes used to paint the investigated artefacts and that may have contaminated the wooden parts examined in the present work.

Among the identified fungi, the genera Alternaria, Aspergillus, Cladosporium and Penicillium (Table 2) were reported as always predominant in indoor and outdoor environments $[28,57]$ and as commonly attacking wooden art objects [15, 18, 22, 58-63]. Three of the four genera, Aspergillus, Cladosporium and Penicillium, are filamentous fungi likely to be the main agents in the alteration of the colour and in the structural deterioration of wood due to their production of cellulolytic and xylanolytic enzymes that degrade the wood fibres [18, 22, 64]. Fungi like Aspergillus and Penicillium may act in low humidity conditions, such as those of our artefacts; they grow in the S2 layer of the secondary cell wall, by enzymatically dissolving cellulose and hemycellulose; they also display a strong amylasic, pectinasic and xylanasic activity and interact with fungi by stimulating their decomposition activity. Thus, the species of these genera may be involved in the formation of the black patinas observed on wood surfaces of all artefacts investigated here [64-67]. In addition, Aspergillus, Fusarium and Penicillium species (Table 2) may have contributed in causing the black patinas, since they are reported to be superficial chromogenic fungi able to grow in the first layers of cells and to a depth not greater than $1 \mathrm{~mm}$ through natural openings or traumatic injuries [64]. Many insects attack wood only after the wood has been altered by fungi [67].

Most fungal species are known to be polyphagous and ubiquitous. Besides present reports on wood decay in artefacts from Naples, in Italy, a series of other reports are indeed available for different geographical areas [1], included reports of species of the genera Cladosporium and Penicillium detected on historical wood in Morocco [68] and of the genera Alternaria, Aspergillus and Penicillium isolated from wooden objects in Iran [69].

As far as the relationships here reported between bacteria and fungi are concerned, it is notable that bacteria grow on the surface of the wood degraded by fungi; these increase the amount of nutrients produced by the decomposition of organic compounds [70]. Then, some bacteria not only have an influence on the permeability of the wood [23], but also attack the structure by working in association with other bacteria or fungi, preparing the wood to fungal attack [14]. It was also proposed that fungi are first colonizers of paintings and wood and that their metabolic products are used by bacteria [7]. In addition, according to Ciferri [2], the bacteria of genus Bacillus cannot grow on paintings by themselves, but only if fungi as Aspergillus and Penicillium promote their survival. Other studies [52, 64] have shown that certain bacterial species induce the degradation of wood according to the ratio that establish with fungi and other xylophagous bacterial species.

Relationships between bacteria and insects were also investigated in the past $[13,20,23,71,72]$. Bacteria are reported to cause the formation of thin galleries within the secondary cell wall of wood $[52,64]$ and this mechanism is facilitated by the presence of xylophagous insects belonging to Anobiidae [23, 26, 48], the family that includes Oligomerus ptilinoides and Nicobium castaneum, the species found on the Artefacts 1 and 4.

The higher diversity of microorganisms discovered on Artefacts 2 and 4, both made of poplar wood, as compared to the lower diversity on the other two artefacts, made up of lime and pear woods, is tentatively interpretable in the light of the different types of wood. Poplar wood might have favoured a more diversified microbial growth due to its greater softness (density $0.3-0.5 \mathrm{~g} \mathrm{~cm}^{-3}$ ), as compared to more compact and hard lime (density $0.65 \mathrm{~g} \mathrm{~cm}^{-3}$ ) and pear $\left(0.6-0.7 \mathrm{~g} \mathrm{~cm}^{-3}\right)$ woods [34].

The fairly high rates of relative humidity and temperature in the rooms where Artefacts 3 and 4 are exhibited (Table 1) may have also been involved in causing the higher biodiversity found on the Artefact 4 (Table 2), where they may have stimulated, in conjunction with the presence of the softer poplar wood, the diversified microbial colonization.

All the results obtained in the present work, besides giving a contribution to the knowledge of micro-habitats represented by biofilms, appear also of interest in the field of conservation of wooden art works colonized by biodeteriogenic organisms. In this respect, they represent a starting point for finding strategies to adopt in the field of cultural heritage restoration. The knowledge of biodeteriogenic species and the type of colonized substrates is often crucial for the choice of suitable techniques to apply in the removal of biofilms.

Acknowledgements The authors thank the personnel at the Conservation Laboratory for Wood Artefacts of the University Suor Orsola Benincasa of Naples, Italy. In particular, authors are grateful to its director, Professor Giancarlo Fatigati, for the collaboration provided and for making all facilities available in the course of this study. The authors also thank Professor Paolo Caputo for his valuable suggestions. 
Finally, the authors thank the anonymous reviewers for their constructive comments.

\section{References}

1. Caneva G, Nugari MP, Salvadori O (2009) Plant biology for cultural heritage: biodeterioration and conservation. The Getty Conservation Institute, Los Angeles

2. Ciferri O (1999) Microbial degradation of paintings. Appl Environ Microbiol 65:879-885

3. Cennamo P, Marzano C, Ciniglia C, Pinto G, Cappelletti P, Caputo P, Pollio A (2012) A survey of the algal flora of anthropogenic caves of Campi Flegrei (Naples, Italy) archeological district. J Caves Karst Stud 74:243-250

4. Cennamo P, Caputo P, Giorgio A, Moretti A, Pasquino N (2013) Biofilms on tuff stones at historical sites: identification and removal by nonthermal effects of radiofrequencies. Microb Ecol 66:659-668

5. Cennamo P, Caputo P, Marzano C, Miller AZ, Saiz-Jimenez C, Moretti A (2016) Diversity of phototrophic components in biofilms from piperno historical stoneworks. Plant Biosyst 150:720-729

6. Cennamo P, Montuori N, Trojsi G, Fatigati G, Moretti A (2016) Biofilms in churches built in grottoes. Sci Total Environ 543:727-738

7. Capodicasa S, Fedi S, Porcelli AM, Zannoni D (2010) The microbial community dwelling on a biodeteriorated 16 th century painting. Int Biodeterior Biodegrad 64:727-733

8. Seves AM, Sora S, Ciferri O (1996) The microbial colonization of oil paintings. A laboratory investigation. Int Biodeterior Biodegrad 37:215-224

9. Sterflinger K, Piñar G (2013) Microbial deterioration of cultural heritage and works of art-tilting at windmills? Appl Microbiol Biotechnol 97:9637-9646

10. Indrayani Y, Yoshimura T, Imamura Y (2008) A novel control strategy for dry-wood termite Incisitermes minor infestation using a bait system. J Wood Sci 54:220-224

11. Horisawa S, Sakuma Y, Chen K, Doi S (2002) Effects of wood species on degradation rates and bacterial communities in a smallscale biodegradation system for garbage using wood matrices. J Wood Sci 48:232-236

12. Clausen CA (1996) Bacterial associations with decaying wood: a review. Int Biodeterior Biodegrad 37:101-107

13. Dicus DH (2000) One response to a collection-wide mold outbreak: how bad can it be, how good can it get? J Am Inst Conserv 39:85-105

14. Florian ML (1993) Conidial fungi (mould) activity on artifact materials: a new look at prevention, control and eradication, pp 868-874. In: ICOM, committee for conservation, tenth triennial meeting, Washington DC http://www.bcin.ca/Interface/openb cin.cgi?submit=submit\&Chinkey=117204. Accessed 28 Feb 2017

15. Schmidt O (2007) Indoor wood-decay basidiomycetes: damage, causal fungi, physiology, identification and characterization, prevention and control. Mycol Prog 6:261-279

16. Kaarakainen $P$, Rintala $H$, Vepsäläinen $A$, Hyvärinen $A$, Nevalainen A, Meklin T (2009) Microbial content of house dust samples determined with qPCR. Sci Total Environ 407:4673-4680

17. Griffin DH (1996) Fungal physiology. Wiley, New York

18. Štafura A, Nagy Š, Bučková M, Puškárová A, Kraková L, Čulík M, Nagy Š, Beronská N, Pangallo D (2017) The influence of microfilamentous fungi on wooden organ pipes: one year investigation. Int Biodeterior Biodegrad 121:139-147

19. Cotter DA (1981) Spore activation. In: Turian G, Hohl HR (eds) The fungal spore. Academic Press, New York, pp 385-411
20. Lupan I, Ianc MB, Kelemen BS, Carpa R, Rosca-Casian O, Chiriac MT, Popescu O (2014) New and old microbial communities colonizing a seventeenth-century wooden church. Folia Microbiol 59:45-51

21. Pangallo D, Chovanová K, Šimonovičová A, Ferianc P (2009) Investigation of microbial community isolated from indoor artworks and air environment: identification, biodegradative abilities, and DNA typing. Can J Microbiol 55:277-287

22. Pangallo D, Šimonovičová A, Chovanová K, Ferianc P (2007) Wooden art objects and the museum environment: identification and biodegradative characteristics of isolated microflora. Lett Appl Microbiol 45:87-94

23. Pangallo D, Bučková M, Kraková L, Puškárová A, Šaková N, Grivalský T, Chovanová K, Zemánková M (2015) Biodeterioration of epoxy resin: a microbial survey through culture-independent and culture-dependent approaches. Environ Microbiol $17: 462-479$

24. Liotta G, Leto Barone G (1989) Methods for the preservation of wooden handworks of artistic and historical interest from the attacks of xylophagous insects (in Italian). In: Tampone G (ed) Restauro del legno. Nardini, Firenze, pp 215-233

25. Brues CT (1936) Evidences of insect activity preserved in fossil wood. J Paleontol 10:637-643

26. Chiappini E, Liotta G, Raguzzini MC, Battisti A (2001) Insects and restoration. Wood, paper, canvas, leather and other materials (in Italian). Calderini, Bologna

27. Schabereiter-Gurtner C, Piñar G, Lubitz W, Rölleke S (2001) An advanced molecular strategy to identify bacterial communities on art objects. J Microbiol Methods 45:77-87

28. Schettini A, Fatigati G, Cennamo P, Moretti A (2010-2011) (Published in 2016) Identification and removal of biodeteriogens on a polychrome wood sculpture, Delpinoa 52-53:47-56. http://www.biologiavegetale.unina.it/delpinoa_files/52-53_4756.pdf. Accessed 28 Feb 2017

29. Borrelli G (2004) The Neapolitan nativity (in Italian). Edizioni Banco di Roma, Roma

30. Fittipaldi T (1980) Neapolitan sculpture of the eighteenth century (in Italian). Liguori, Napoli

31. Leone De Castris P, Middione R (1986) The painting of the Girolamini (in Italian). Guida, Napoli

32. Fatigati G (2010) The arts of wood: nature, property and problems of materials in the preservation of art works (in Italian). Quaderni della ricerca scientifica, Serie Beni Culturali, 17. Published by Università degli Studi Suor Orsola Benincasa di Napoli, Naples, Italy

33. Berti S, Lazzeri S, Macchioni N, Sozzi L (2002) Xylotheca Project. Wood database and software for identification of species by dichotomous keys. Version for MS-Windows operating systems (in Italian). I.Va.L.S.A. G. L. Vottero, Ecodata, Italy http://www.netsilva.org/silvasito/Arsia/Xyloteca.htm. Accessed February 2017

34. Schweingruber FH (1990) Anatomie Europäischer Hölzer. Ein Atlas zur Bestimmung europäischer Baum-, Strauch- und Zwergstrauchhölzer (in Germany). Paul Haupt, Bern

35. Milanesi C, Baldi F, Vignani R, Ciampolini F, Faleri C, Cresti $M$ (2006) Fungal deterioration of medieval wall fresco determined by analysing small fragments copper. Int Biodeterior Biodegrad 57:7-13

36. Norris JR, Ribbons DW (1969) Methods in microbiology, vol 1. Academic Press, London

37. Bertani G (1951) Studies on lysogenesis. I. The mode of phage liberation by lysogenic Escherichia coli. J Bacteriol 62:293-300

38. Doyle JJ (1990) Isolation of plant DNA from fresh tissue. Focus 12:13-15 
39. Neefs JM, Van de Peer Y, Hendriks L, De Wachter R (1990) Compilation of small ribosomal subunit RNA sequences. Nucleic Acids Res 18:2237-2317

40. White TJ, Bruns T, Lee S, Taylor JW (1990) Amplification and direct sequencing of fungal ribosomal RNA genes for phylogenetics. In: Innis MA, Gelfand DH, Sninsky JJ, White TJ (eds) PCR protocols: a guide to methods and applications. Academic Press, Orlando, pp 315-322

41. Muyzer G, de Waal EAC, Uitterlinden AG (1993) Profiling of complex microbial populations by denaturing gradient gel electrophoresis analysis of polymerase chain reaction-amplified genes coding for 16S rRNA. Appl Environ Microbiol 59:695-700

42. Teske A, Wawer C, Muyzer G, Ramsing NB (1996) Distribution of sulfate-reducing bacteria in a stratified fjord (Mariager Fjord, Denmark) as evaluated by most-probable-number counts and denaturing gradient gel electrophoresis of PCR-amplified ribosomal DNA fragments. Appl Environ Microbiol 62:1405-1415

43. Buchan A, Newell SY, Moreta JIL, Moran MA (2002) Analysis of internal transcribed spacer (ITS) regions of rRNA genes in fungal communities in a south-easternU.S. salt marsh. Microb Ecol 43:329-340

44. Michaelsen A, Pinzari F, Ripka K, Lubitz K, Piñar G (2006) Application of molecular techniques for the identification of fungal communities colonising paper material. Int Biodeterior Biodegrad 58:133-141

45. Hall TA (1999) BioEdit: a user-friendly biological sequence alignment editor and analysis program for Windows 95/98/NT, 41. Nucleic Acids Symposium Series, Oxford University Press, pp 95-98

46. Ministero per i Beni e le Attività Culturali (2001) Scientific technical criteria and standards of operation and management of museums (in Italian). Photometric controls, recommended lighting, pp. 129-130. Microclimatic conditions for the prevention of microbiological attacks on organic materials. pp 148-150. http:// musei.beniculturali.it/wp-content/uploads/2016/04/Atto-di-indir izzo-sui-criteri-tecnico-scientifici-e-sugli-standard-di-funzioname nto-e-sviluppo-dei-musei-DM-10-maggio-2001.pdf Accessed February 2017

47. Perusini G (2004) The restoration of paintings and wooden sculptures. History, theories and techniques (in Italian). Del Bianco Editore, Hoepli.it, Italy

48. Gambetta A (2010) Fungi and insects in the wood. Diagnosis, prevention, control (in Italian). Nardini Editore, Firenze

49. Fromin N, Hamelin J, Tarnawski S, Roesti D, Jourdain-Miserez K, Forestier N, Teyssier-Cuvelle S, Gillet F, Aragno M, Rossi P (2002) Statistical analysis of denaturing gel electrophoresis (DGE) fingerprinting patterns. Environ Microbiol 4:634-643

50. Schippers A, Bosecker K, Spröer C, Schumann P (2005) Microbacterium oleivorans sp. nov. and Microbacterium hydrocarbonoxydans sp. nov., novel crude-oil-degrading Gram-positive bacteria. Int J Syst Evol Microbiol 55:655-660

51. Kim YK, Lee SC, Cho YY, Oh HJ, Ko YH (2012) Isolation of cellulolytic Bacillus subtilis strains from agricultural environments. ISRN Microbiol 2012:650563

52. Vimal J, Venu A, Jini J (2016) Isolation and identification of cellulose degrading bacteria and optimization of the cellulose production. Int J Res Biosciences 5(3):58-67

53. Khalid A, Kausar F, Arshad M, Mahmood T, Ahmed I (2012) Accelerated decolorization of reactive azo dyes under saline conditions by bacteria isolated from Arabian seawater sediment. Appl Microbiol Biotechnol 96:1599-1606

54. Qian J, Hospodsky D, Yamamoto N, Nazaroff WW, Peccia J (2012) Size-resolved emission rates of airborne bacteria and fungi in an occupied classroom. Indoor Air 22:339-351
55. Fajardo-Cavazos P, Nicholson W (2006) Bacillus endospores isolated from granite: close molecular relationships to globally distributed Bacillus spp. from endolithic and extreme environments. Appl Environ Microbiol 72:2856-2863

56. Osman S, Peeters Z, La Duc MT, Mancinelli R, Ehrenfreund P, Venkateswaran K (2008) Effect of shadowing on survival of bacteria under conditions simulating the Martian atmosphere and UV radiation. Appl Environ Microbiol 74:959-970

57. Rivas R, Mateos PF, Martínez-Molina E, Velázquez E (2005) Paenibacillus xylanilyticus sp. nov., an airborne xylanolytic bacterium. Int J Syst Evol Microbiol 55:405-408

58. Rayner ADM, Boddy L (1988) Fungal decomposition of wood: its biology and ecology. Wiley, New York

59. Sterflinger K (2010) Fungi: their role in deterioration of cultural heritage. Fungal Biol Rev 24:47-55

60. Strzelczyk AB (2004) Observations on aesthetic and structural changes induced in Polish historic objects by microorganisms. Int Biodeterior Biodegrad 53:151-156

61. Sterflinger K, Pinzari F (2012) The revenge of time: fungal deterioration of cultural heritage with particular reference to books, paper and parchment. Environ Microbiol 14:559-566

62. Pournou A, Bogomolova E (2009) Fungal colonization on excavated prehistoric wood: implications for in-situ display. Int Biodeterior Biodegrad 63:371-378

63. Tavzes C, Pohleven J, Pohleven F, Koestler RJ (2003) Anoxic eradication of fungi in wooden objects. In: Koestler RJ, Koestler VH, Charola AE, Nieto-Fernandez FE (eds) Art, biology, and conservation: biodeterioration of works of art. The Metropolitan Museum of Art, New York, pp 426-439

64. Blanchette RA (2000) A review of microbial deterioration found in archaeological wood from different environments. Int Biodeterior Biodegrad 46:189-204

65. Fazio AT, Papinutti L, Gómez BA, Parera SD, Rodríguez Romero A, Siracusano G, Maier MS (2010) Fungal deterioration of a Jesuit South American polychrome wood sculpture. Int Biodeterior Biodegrad 64:694-701

66. Ortiz R, Navarrete H, Navarrete J, Párraga M, Carrasco I, de la Vega E, Ortiz M, Herrera P, Blanchette RA (2014) Deterioration, decay and identification of fungi isolated from wooden structures at the Humberstone and Santa Laura saltpeter works: a world heritage site in Chile. Int Biodeterior Biodegrad 86:309-316

67. Rosado T, Silva M, Pereira C, Mirão J, Candeias A, Caldeira AT (2015) Gilded woodcarving alteration: assessment of filamentous fungi action. Int J Conserv Sci 6:499-506

68. Zyani M, Mortabit D, Mostakim M, Iraqui M, Haggoud A, Ettayebi M, Koraichi SI (2009) Cellulolytic potential of fungi in wood degradation from an old house at the Medina of Fez. Ann Microbiol 59:699-704

69. Ebrahimi A, Karimi S, Lotfalian S, Majidi F (2011) Allergenic fungi in deteriorating historic objects of Shahrekord Museum, in Iran. Jundishapur J Microbiol 4:261-265

70. Bruez E, Haidar R, Alou MT, Vallance J, Bertsch C, Mazet F, Fermaud M, Deschamps A, Guerin-Dubrana L, Compant S, Rey $P$ (2015) Bacteria in a wood fungal disease: characterization of bacterial communities in wood tissues of esca-foliar symptomatic and asymptomatic grapevines. Front Microbiol 6:1137

71. Ulyshen MD (2014) Wood decomposition as influenced by invertebrates. Biol Rev Biol Proc Cambridge Philos Soc 91:70-85

72. Holt DM, Jones EBG (1983) Bacterial degradation of lignified wood cell walls in anaerobic aquatic habitats. Appl Environ Microbiol 46:722-727 